\title{
Performance Standards Public Accountability Forces Investigation
}

\author{
${ }^{1}$ Dr. Suharto, M.Hum. ${ }^{2}$ Dr. Budi Rianto. M.Si., ${ }^{3}$ Dra. Ec. Tri Lestari, M.Si. \\ ${ }^{1}$ Law Science Department, Post Graduate, Bhayangkara University, Surabaya , East Java of Indonesia. \\ 2 Public Administration, Post Graduat, Hang Tuah University Surabaya East Java of Indonesia. \\ ${ }^{3}$ Accounting Department, Faculty of Economics, Bhayangkara University Surabaya , East Java of Indonesia
}

\begin{abstract}
The purpose of this study are: to describe and analyze the accountability standards of criminal investigations by the authorities of detectives in the East Java Regional Police

This research design using a model participant action research, action research and empirical diagnosis of action research, while the object of research is the investigation of Performance Accountability Implementation in the East Java Police, with research sites and the General Office of Special Direskrim East Java Police. Analysis techniques used in this research is the analysis of interactive models

The results showed that in the East Java Police, Criminal Ditserse tasks in the East Java Police, from year to year indicates declining performance in the process of crime prevention (Crime Clearence). On the other hand are more qualified crime patterns, with the use of technology to eliminate evidence various also by increasingly sophisticated criminals.
\end{abstract}

Keywords: Public Accountability Standards, The Performance Of Forces

\section{Introduction}

Governance reform in Indonesia that took place in the late 1990s, showed that the actualization demands of good governance (good governance) of the people, by the people and for the people can not be postponed again to be a major concern. One of his demands is reform towards civil society, following the MPR enactment VI/MPR/2000 Number of Partition Indonesian Armed Forces (TNI) and the Indonesian National Police (INP) and No. VII/MPR/2000 Tap on the Role of the military and police . Followed by the issuance of Law No.: 2 of 2002 (1), of the Indonesian National Police and the Law of the Republic of Indonesia No. 3 of 2002 on National Defence (2),

The tendency of the police as an institution rather solve problems rather than prevent it already happened long ago. As said Jusuf (2007) (3), that: "The task of completing the case seem more heroic and be profitable, either material or career." Though the police presence is expected to be closer and more trusted in society as protectors, guardian and steward a clean, dignified, transparent and professional, and that is no less important is accountable.

Unity basic operational police organization of the Republic of Indonesia can be divided into basic police duties as follows ::

1. Intelligence task

2. Investigation task

3. Sabhara (Police Patrol)

4. Traffic (Traffic Police), and

5. Guidance (Guidance Society)

Intelligence and Investigation task is referred to as Non-Uniform Police / Plain Cloth Police, while Sabhara tasks, including traffic and Guidance Uniform Police.

Diats of various organizational tasks, in order of security and public order duties by institution police, which is the primary law enforcement duties (Law Inforcement),

where the unit of detectives organizations have an important role in law enforcement for a variety of criminal offenses that occur in the community, so the criminal investigation unit is also referred to as Core Business Police in its function of law enforcement in order to maintain security and public order in the country.

Investigation as "Core Bussiness Unit" Police in carrying out the duty of care, guidance and safeguards the public from crime, must be accountable for their duties before the public, so research with the object of accountability standards in the organization of the national police investigation is expected to be able to significantly improve performance accountability Ditresrkim East Java Police in particular and confidence in the performance of the police in general. So it can be used for benchmarking efforts for the improvement of good governance in the work environment

The Importance of Performance Accountability in Public Service Investigation Good performance of the investigation, as a form of public service is still in the spotlight and expectations of 
society . Criminal crime, much remains to be a police detective officers homework unfinished, so that their performance and professional proportionately less often into the public spotlight. Standard performance is important to be presented in this organization, given their task is closely connected to the community . Performance standards, when it has understood itself open to both the police and the community in general, can provide a thorough understanding of the performance of drawing police handling of crime in society .

\section{Performance Accountability Standards Service has many public sector}

organizations operating in the private and public organizations. Standard formulation of good quality, which can meet the service needs of communities without any discrimination, to the urgent need in the era of democracy and respect for human rights today .

\section{Ideal models , Easily Achieved Excellent Service and Minimum Standards}

Various details of model building as a standard or guideline that " service providers" of public sector organizations, can provide quality services for the community or the prime users of these services . Charlotte Williamson (1992) ( 4 ), said that : " to provide a model or standard for measurable aspects that exist in the service in order to satisfy every interest of consumers and professionals, it takes a considerable synergies to perform these services" .

The concepts of quality public services that is considered by the government is a " Citizen 's Charter " ( charter citizenship ). For example, in New York in 1989 was published the first time a consumer contracts on environmental services, such as street cleaners. Before the contract is formulated, first public consultation was also conducted on the priorities that should be done and also audit forms that have already been there . Each stakeholder has a different opinion about the model or standard, but not all of the wishes of the stakeholders can be met. There fore, service providers need to identify what the priorities of each community .

\section{Research Methods}

This research design using models such research participant action research, action research and empirical diagnosis action research ( Kemmis \& Taggart, 1988) ( 5 ), . In addition to the high levels of scholarship have been kind of research is also consistent with the objectives of research that produced the model of public service accountability . At this stage of the needs assessment will be used method of focus group discussion. This method is very good to explore data from the East Java Police officers Direskrim, because with this method they can express their opinions openly and groups. ( Muthir, 1991) ( 6 ), .

Object of this study is the investigation of Performance Accountability Implementation in the East Java Police, with research sites and the General Office of Special Direskrim East Java Police .

The technique used to collect the data was the focus group discussions, observation and documentation . Focus group discussions were supported by interviews are used to identify the interests and needs of officers and citizens, as well as a variety of potential accountability excellent service which will allow it to be developed

Observation is used to observe the condition and potential that can be developed through the existing technology , which was developed and used as a means of improving organizational performance in the Ditreskrim .

Documentation is used to capture data relating to the data stored in Office documents Ditreskrim that can be used to support the research process .

Data analysis was performed using the approach, the qualitative approach . Qualitative data were analyzed qualitatively based on logical thinking. Of the Ditreskrim office, descriptive analysis to obtain general conclusions, Public Accountability Standards of performance are developed in the Ditreskrim office .

Analysis techniques used in this research is the analysis of interactive models as developed by Miles and Huberman (1984) ( 7), which consists of three (3) components of the analysis, namely (i ) data reduction , (ii) presentation of data, and ( iii ) conclusion.

\section{Results And Discussion.}

Office of the Directorate of Criminal Investigation Police of East Java Regional Police Headquarters is located in East Java (East Java Police Headquarters) located on road Ahmad Yani 113, Surabaya. Is one of the East Java Police organizational units that handle a variety of environmental crimes in the area of East Java Police.

\section{Personnel Investigation officials in East Java Police.}

To handle any kind of threat to security and public order in East Java then has held a number of personnel who are specifically given the task and responsibility to investigate and prosecute criminal cases that occur are members of the directorate of the East Java Police criminal detectives in Table 1; below will be 
juxtaposed data on the number of personnel throughout the Indonesian National Police, the Police throughout the East Java Police, detectives throughout the ranks of the East Java Police.

Table: 1. Number of police personnel in East Java, East Java Police personnel at the Police Headquarters, Detective personnel and the number of personnel in the East Java Police Headquarters Investigation in Java / Java Ditreskrim.

\begin{tabular}{|l|l|c|}
\hline NO & Indonesian Police (national police) & TOTAL PERSONNEL \\
\hline 1 & Police in Indonesia & 275.294 \\
\hline 2 & Police in East Java & 39.720 \\
\hline 3 & Police headquarters in East Java regional police & 5.107 \\
\hline 4 & Personnel detectives in east Java & 3.816 \\
\hline 5 & Personnel direskrim Police detectives in east Java & 238 \\
\hline
\end{tabular}

Source: Bureau of East Java Police Personnel on though (2013).

The development of the number of cases rise and fall of crime rates that occurred very influenced kriminogin correlative factors that social factors, economic, political, cultural, legal and others developed in the community, we know that the socio-economic issues, culture, politics in Java east so complex and affect the security situation of the local, regional and national.

Police performance in the completion of a criminal case is often questioned by the public, problem resolution or disclosure of crimes is the duty area of the apparatus of detectives, detective agencies so that performance can be said to be very decisive for the performance of the detectives assigned unitary authorities. The performance of East Java Police Directorate Criminal Investigation Criminal Case for settlement during the period of 2009 up to year 2013, can be seen in the following table.

Table: 2. Performance East Java Police Criminal Investigation Directorate in order Criminal settlement Year 2009-2013.

\begin{tabular}{|c|c|c|c|c|c|c|c|c|}
\hline \multirow[t]{2}{*}{ NO } & \multirow[t]{2}{*}{ YEAR } & \multicolumn{3}{|c|}{ Police RANGE JATIM } & \multicolumn{3}{|c|}{ Directorate of Criminal Police east java } & \multirow[t]{2}{*}{ information } \\
\hline & & $\begin{array}{l}\text { CRIME } \\
\text { TOTAL }\end{array}$ & $\begin{array}{c}\text { CRIME } \\
\text { CLEARANCE }\end{array}$ & $\%$ & $\begin{array}{l}\text { CRIME } \\
\text { TOTAL }\end{array}$ & $\begin{array}{c}\text { CRIME } \\
\text { CLEARANCE }\end{array}$ & $\%$ & \\
\hline 1 & 2009 & 37612 & 29007 & 77,12 & 532 & 428 & 80,45 & \\
\hline 2 & 2010 & 31373 & 22422 & 71,46 & 772 & 392 & 50,77 & \\
\hline 3 & 2011 & 35968 & 25997 & 72,77 & 821 & 385 & 46,89 & \\
\hline 4 & 2012 & 27942 & 20226 & 72,38 & 630 & 199 & 31,58 & \\
\hline 5 & 2013 & 71045 & 58278 & 82,02 & 1025 & 506 & 49,36 & \\
\hline
\end{tabular}

Source: Directorate Reskrim East Java Police (2013)

From the table above shows that in the East Java Police, Criminal Ditserse tasks in the East Java Police, from year to year indicates declining performance in the process of crime prevention (Crime Clearence). On the other hand are more qualified crime patterns, with the use of technology to eliminate evidence various also by increasingly sophisticated criminals. A criminal investigation officers should be provided with sufficient additional individual ability to determine the attitude, if someone needs suspected perpetrators of crimes or not.

STANDARD OPERATING PROCEDURE FOR IMPLEMENTATION OF INVESTIGATION and consequently

The results showed that in accordance with SOP Inquiry and Investigation issued by the Criminal Investigation DIRECTOR GENERAL, East Java Police in February 2012 shows that the SOP was issued over the investigation and implementation guidelines for the investigation detectives prevailing forces in the East Java Police Board. However, information about legal actions for officials who do not enforce the SOP, not be set separately in the SOP, so that legal action against officials who are not carrying out SOP, still based on the general provisions of the applicable disciplinary officials in the Indonesian National Police in general. Thus in the context of legal action has not been specifically SOP violations in its own set, and performance-related remuneration institutional environment has been prevailing in the Indonesian National Police.

\section{Terminology}

Standard Operating Procedures issued by the Director of the East Java Police Detective, is a guideline for the implementation of task forces in the East Java Police detectives, rather than a " Charter and Promises " which can also be guided by the people who are involved in cases related to the investigation and police detectives investigating officers East Java . So if there is a violation of standard operating procedures that have 
been issued, and not effectively impact the criminal investigation apparatus itself and for the people who are victims of violations of the SOP . So natural that, after the issuance of the SOP, there still Friess Ermessen or policies of the authorities investigate and prosecute perpetrators even to the use of authority in the performance of duties, within certain limits, which do not give rise to a broad public impact . It is as expressed by Heru ( interview , June 30, 2013 ) ( 8 ), as follows : "If we want the report to be processed pack of disposable money , so the need to charge and win the case we report, and even then not necessarily win of cases or matters that we reported to Police. If not then deflated at the level of the Prosecutor ". Thus it can be said that the street -level bureaucracy ( Boven , 2001) (9) , is still so dominant in handling a variety of cases , in the East Java Police detectives

\section{How each Standard Implemented ?}

Standard Operating Procedure in the East Java Police Reskrim general, still the initiation and socialization in the process of implementing the ranks of law enforcement in the East Java Police, this can be seen from the product itself that is SOP bandwagon product of :

" Police have 10 commitments in leadership meeting proclaimed by the Chief of Police at National Police in Jakarta from 18 to 24 January 2012 and simultaneously swore by all members of the Police in East Java Police and ranks, which is the ability of every member of the Police pledge to strive better in ministry to the community " . ( source RESKRIM general East Java Police SOP ) ( 10 ), .

\section{Establishment of goals Standards}

The purpose of establishing accountability standards as efforts to develop public service performance, has been revealed in the SOP issued by the Directorate of Criminal Investigation Police of East Java, as specified in the SOP informed about the results of the investigation to the complainant through the provision SP2HP time. So the quality pelayanana described in the SOP to improve public services, choice and value that has been set. Also based on the principles of public services there, have a standard agreement should be made to our clients and staff assistance to be provided by the staff of the service to clients .

\section{Characteristics}

In the execution of the duties of investigation, standard operating procedures that have been published by the East Java Police Direskrim, at least has provided the impetus for the implementation of the investigative task by default, as it has been published in the SOP . Even if the SOP has been published in its implementation, difficulties are still a lot of practice because of SOP that has been made, has not been supported by adequate infrastructure and facilities as specified in the SOP. SOPs which have been published in addition to not encourage the service provider level organizational unit at the police station, the SOP becomes less useful in improving the quality of service and investigation at the organizational unit level, so that the expected impact in improving the quality of services of detectives have not been able to run optimally .

\section{Various objective Improvement Standards}

From the observations indicate that aspects of community development, can not be said to have a significant association for community empowerment process in this case is closely related to the assignment portion of East Java Police Community Guidance. SOP for the sake of openness about various things, it can be seen from the results of the interview as follows :

" The regional police ditreskrim general east java, making the SOP for the benefit of the report to the chairman ( Chief of Police ) and performance standards for the benefit of detective agencies in our environment , to work in accordance with standard operating procedures we have set. As a guide to performance guidelines and action steps for authorities investigating detectives " ( FGD , June 11, 2013 ) (11 ),

\section{Involvement in the establishment of standards}

From the results of observation in the East Java Police Ditreskrimum office, until recently due to the issuance of the SOP, still in the context of the guidelines among internal personnel investigation detectives in the performance of duties.

"In addition, the creation of standard operating procedures, are made based on existing law so that from the aspect of community involvement, has been represented in the legislative process in the forum that is the House of Representatives, as the embodiment of a part of the Criminal Justice System in Indonesia. So it is no longer needed direct involvement of the community in the process of drafting the SOP, but the involvement of the executive in the process is clearly very necessary. "(FGD, 11.06.2013) (11),

From the results of these discussions, it can be argued here that the establishment of standards have been set forth in the Police Act and the rules and regulations of the higher this SOP, just issue a more detailed technical description for the officers executing the task of detectives in the investigation process so that they can run optimally, accordance with the provisions of the applicable legislation. In addition to the criminal 
investigation officers in the field can be a reminder of the procedure as well as action steps and the investigation should not be done while in the field.

\section{In the role of Artificial}

In regard to the role of standards here, with the enactment of the performance standards in the police investigation process by applicable law, all equally valid throughout the territory of the Republic of Indonesia. However, in its implementation, in every region has its regional context of each national standard so that even the same performance, the law is the same as the reference. Policy in the field greatly affects the output performance of the apparatus officer. In addition, the role and actions of officials on the ground are very big influence on the performance put out investigations on specific cases. Thus even if the soup together, the quality of their human resources is very important and has a dominant role to the success of the process of criminal investigations in uncovering the crime scene crime in society.

\section{Local and national standards}

National standards issued in two ways, namely through the adoption of legislation or standards, such as that conducted by the House of Representatives in the form of laws and regulations of the President or Chief of Police at the national level. However, the police force of East Java, especially East Java Police have issued Ditreskrim general SOP for the criminal investigations unit in the detective officers of this organization. Performance in order to be able to walk in the corridors of applicable law and in accordance with the operational standards that have been set.

\section{Maximum and Minimum Standards; Use Procedures and Guidelines}

Standard can be used at different levels and in different types of services: First, the minimum basic services, with the issuance of the SOP has been stated clearly in writing the performance standards that must be achieved. Second, the maximum standard as a target that can be achieved within a specified time from the Crime Clearance by Ditreskrim general reported regularly to the public, both qualitatively and quantitatively.

Third, all procedures for handling cases of various aspects of the well of time, openness, and others have publicly stated in SOP published. However, from the aspect of incentives and disincentives have not publicly stated in the SOP.

\section{Measurement Standards and Targets}

Standards issued by the East Java Police Ditreskim general, superbly standards and targets to be raw, for the authorities in the East Java Police detectives in particular that based on the SOP, the leader can set standards and performance targets officials more openly and definitely. It's just for the community as part of the consumer, still have not become part of a system that is open and known to deal in general.

\section{Gifts and Incentives}

With the implementation of the remuneration system in the salary system in the police, it turns out from the results of studies have not shown a strong correlation between the implementation of performance standards with income or incentives offered by the institution to the detective officers, so the phenomenon of charging operating expenses to the complainant is still going on in various handling of criminal cases in the community.

\section{Conclusion}

\section{Standardization of Performance for Public Accountability.}

East Java Police criminal detective agency, as the unit responsible for the investigation of environmental crimes in East Java Police criminal, in the next stage automatically woke up in a standard operating procedure that is more stable as the embodiment of standard accountability to the public. Furthermore, based on the existing provisions, may declare its commitment to carry out its functions as possible.

\section{Organizational Performance Standards for Criminal Investigation Crime}

With the issuance of the SOP, standard set of organizational performance that can provide certainty to consumers (society) and the implementing agency itself, in taking action and investigation in a variety of cases that must be handled. So that the organization can function optimally in accordance with established organizational and system performance takes place within the specified quality standards and sustainable. 


\section{Theoretical}

\section{Suggestions}

a. The existence of public bureaucracy inseparable from the development perspective of the system of government and the local community. Similarly, the meaning of the resulting effectiveness of criminal investigations by the performance of organizational units that handle, as accountable to the public. Therefore, in a democratic system of government in order to achieve effective and efficient performance, should provide ample opportunities to the community as a customer of his performance in the investigation of criminal offenses are dealt with by the public organizations.

b. Standardization of organizational performance to be more effective and efficient if supported by the application of information technology, in addition to producing professional standard, a standard structure and investigation procedures, minimum standards of provision of adequate facilities and infrastructure, as well as the patterns of leadership (managerial)-oriented accountability to the public, and which can be accounted for on the employer and its parent agency, and accepted by the community and citizens.

\section{Practical}

a. Given the importance of standardization in the implementation of the performance of organizational performance to fit the goals of the organization, investigating criminal offenses performance standards should be clear and open to the public, so it allows the realization of organizational performance standards are effective and efficient.

b. Forms of organization that are relevant to the vision and mission of the organization, so the success of the investigation of criminal offenses in the East Java Police Investigations Bureau, with the enactment of a clear standard operating procedures and standard. Therefore SOP openness and socialization is very important in order to achieve optimal performance.

\section{References}

[1]. Law No: 2 of 2002 on the Indonesian National Police (REPUBLIC OF INDONESIA IN 2002 NUMBER 2, file :/ / / C :/ Users/COREI3 1/AppData/Local/Temp/UU_NO_2_2002.HTM

[2]. The laws of the Republic of Indonesia No. $\overline{3}$ of 2002 on National Defence, http://tempo.co.id/hg/peraturan/2004/03/24/prn 0.20040324-01, id.html

[3]. Joseph, 2007, interview

[4]. Williamson, Charlotte, 1992, Whose Standard? Consumer and Professional Standard in Health Care, Open University Press, Buckingham, Philadelphia.

[5]. Kemmis, Stephen and Robin McTaggart (eds.), 1988. The action research planner. Victoria, Australia: Deakin University Press.

[6]. Muthir, 1991, ... up the ranks of the intelligence service up to become Director General of Intelligence and then prime minister

[7]. Miles, Methew, B and Michael Huberman. , 1987. Qualitative Data Analysis A Shourcebook of A New Method. Sage Publications Beverly Hills, London, New Delhi

[8]. Heru Herlambang, Interview, June 17, 2013

[9]. Bovens, Mark \& Zouridis, 2002, From street-level to system-level bureaucracies: How information and communication technology is transforming administrative discretion and constitutional control, Public Administration Review, March / April, Vol. 62.No. 2.

[10]. (source: Standard Operating Procedure, published by the Directorate General of Criminal Investigation East Java Regional Police), in 2012.

[11]. Focus Group Discussion, dated June 11, 2013), 